\title{
GROSS DOMESTIC PRODUCT (GDP) AND GROSS NATIONAL PRODUCT (GNP)
}

\author{
Antonio Argandoña
}




\title{
GROSS DOMESTIC PRODUCT (GDP) AND GROSS NATIONAL PRODUCT (GNP)
}

\author{
Antonio Argandoña ${ }^{1}$
}

\begin{abstract}
This work is an entry for the second edition of Sage's Encyclopedia of Business Ethics and Society. It provides an explanation of the concepts of gross domestic product and gross national product, their economic significance and their ethical implications. Although both GDP and GNP are technical quantities, they have considerable ethical significance because they refer to the population's standard of living and to growth policy objectives. In any case, it is important not to confuse GDP with human well-being or welfare. The limitations of GDP and the alternatives that have been proposed to overcome them are discussed.
\end{abstract}

Keywords: Gross domestic product; Gross national product; National accounts; Ethics

1 "La Caixa" Chair of Corporate Social Responsibility and Corporate Governance 


\section{GROSS DOMESTIC PRODUCT (GDP) AND GROSS NATIONAL PRODUCT (GNP)}

\section{Introduction}

As early as the 19th century, the need to compile information on the evolution of an economy over time prompted economists to develop aggregate calculations of a country's total production. In 1942, the U.S. Department of Commerce published the first official set of national accounts to measure the country's economic variables, the most important variables being gross domestic product (GDP) and gross national product (GNP). The latter was calculated for the first time in the 1930s to help get the U.S. economy out of the Great Depression, which itself shows the objective that its calculation aimed to achieve. Although both GDP and GNP are technical quantities, they have considerable ethical significance because they refer to the population's standard of living and to growth policy objectives.

GDP is the market value of the final goods and services produced in a country in a given period at market prices. GNP evaluates the goods and services produced by the domestically owned factors of production. GDP refers to goods and services produced within the country by factors of production owned by residents and nonresidents alike. GNP refers to goods and services produced by factors of production owned by residents, whether the production takes place within the country or abroad. For example, the salary of a U.S. manager who works occasionally in Belgium will be included in Belgium's GDP but not in its GNP. Conversely, it will be included in the United States' GNP but not in its GDP. In what follows, when we speak of GDP we will be referring also to GNP.

Formally, GNP is equal to GDP plus any income (from labor and capital) earned abroad by domestic factors, less income earned within the country by foreign factors. GDP is used more often, especially for comparisons between countries. The differences between the two measures is often small but not always. In 2014 the Republic of Ireland's GNP was equal to 86\% of its GDP. The difference, which was even higher in previous years, was due to the high volume of foreign investment in the country, the return on which was included in its GDP but not in its GNP. That may have provoked an ethical problem: the possible manipulation of transfer prices by multinational companies in order to generate most of their profits in Ireland, whose tax policy was particularly favorable to them. 


\section{The Economic Dimension of GDP}

In GDP, the goods and services produced are aggregated in terms of value - that is, in terms of the prices paid by the buyers. Because some goods are used to produce other goods (for example, steel is used in the production of cars), adding up the value of all the products would lead to "double counting" (the steel would be counted twice - once as a product of the steel industry and again as part of the value of the automobiles). To avoid that, only final goods are taken into account - that is, goods that are not used in the production of other goods (in our example, the cars but not the steel). Alternatively, we can add up the "value added" by each production unit (the value the steel company adds to the raw materials, supplies and energy purchased from other companies, and the value the automaker adds to the value of the raw materials and supplies obtained from other industries, etc.).

GDP is gross product in that it does not consider the depreciation of productive equipment or the depletion of natural resources, consideration of which would lead to net national product (NNP) or net domestic product (NDP). This would be a more refined measure of the standard of living of a country but GDP is preferred because of the difficulty of accurately estimating the depreciation of capital stock and also because, for certain purposes, GDP is a more appropriate measure: for example, to determine the contribution of the product to the creation of employment. Last but not least, GDP is preferred because it is greater than NDP.

To compare the GDP of two different periods, we need to separate the change in physical output from any mere change in prices. To do that, the "real" GDP is calculated using the prices of a given year (known as the base year, which is often the previous year).

As we have seen, GDP contains information about the scale and composition of a country's production, the income it generates (what is called the national or domestic income), the size and make-up of what its population spends (in other words, an approximate measure of the standard of living of its population), and how these variables have changed over time. GDP may be seen from three roughly equivalent points of view:

1) Expenditure-based: the value of domestic final expenditure on goods and services. This includes purchases of consumer goods and services by households, gross private investment in structures, equipment and software, residential investment and change in inventories, and government consumption and investment, plus the value of exports, less the value of imports.

2) Income-based: all payments made in production, such as wages and other labor costs, interest, rental costs, depreciation, profit, and taxes paid by companies, less subsidies.

3) Output-based: the sum of the value added by all the production units, plus net taxes paid.

Knowing the GDP of two countries allows us to compare them, although this raises at least two further questions. One is what common currency to use for the comparison because any changes in the exchange rate of the chosen currency (for example, the U.S. dollar or the euro) may give rise to spurious changes in our comparisons. The other complication is the fact that the purchasing power of the same monetary unit may be very different in different countries: although a dollar is a dollar, whether in the United States or in India, you can buy a lot more with a dollar in New Delhi than you can in New York. For that reason, international comparisons tend to be made in terms of purchasing power parity, which corrects that effect. 


\section{Limitations of GDP}

GDP is a useful economic concept but it is important to be aware of its meaning and its limitations in economic, social and ethical terms. (Stiglitz, Sen and Fitoussi are critical of the notion of GDP.)

1) GDP includes the goods and services that are the object of exchange in the market, for which there are set market prices, plus certain other goods, such as the services of owneroccupied housing or the consumption of farm produce by farmers, for which prices are imputed. However, it excludes many goods and services that are not the object of exchange in the market, such as housework, childcare and elder care (when not carried out as paid work) and voluntary work. In other words, its scope is limited.

2) Some countries, such as the United States, do not include illegal activities (drug trafficking, smuggling, prostitution) or undeclared activities (the underground economy). However, in 2008 the United Nations recommended as a "best practice" the inclusion of the value of these illegal activities, and the European Union introduced them in the ESA 2010 standard. This implies an extension of GDP's content but at the cost of less precision because the figures for illegal activities are based on gross estimates. On the other hand, once it has been admitted that these activities contribute positively to GDP, there is likely to be increased pressure to consider them as legal or ethically correct.

3) It does not include activities entailing mere transfers of assets between people, such as the sale of a house, the sale of a company's shares, the increase in value of works of art, donations, or thefts, because they do not represent new production of goods and services.

4) GDP does not measure a country's accumulated wealth, but only the value of the goods and services produced in one period. If, for example, a natural disaster destroys part of the country's productive resources, this will not be reflected directly in the country's GDP although it will be reflected indirectly if the final production is reduced as a result of the destruction.

5) It does not include the value of leisure - though it is assumed that the market wage should reflect this, at least ideally. Nor does it include spiritual, moral or cultural values, unless they are reflected in the production of goods and services.

6) Market prices do not reflect all the opportunity costs of production, nor the harm (or the benefits) caused by economic activity outside the market, such as environmental damage or traffic congestion. Paradoxically, GDP may not reflect the environmental damage caused by production or the insecurity resulting from crime and yet it will reflect the value of the goods and services produced in order to combat those ills. In particular, the productive use of nonrenewable resources increases GDP but their depletion does not lead to its reduction.

GDP is a powerful statistical measure if its limitations are recognized. Failure to take them into account can lead to erroneous recommendations. An example would be proposing the growth of GDP as the sole or main goal of the development policy of poor countries. In fact, GDP does not capture sufficiently the informal economy, the contribution of subsistence farming and other localized forms of production and consumption, which are very important in low-income countries. 
Accordingly, a policy of growth centered on GDP favors the formal sector (e.g., shopping malls, commercial farming, large infrastructure) at the expense of the informal (e.g., street vendors, subsistence farming, flea markets and household production), the big at the expense of the small, and the exploitation of natural resources - which have to be commoditized to become productive - at the expense of their long-term conservation as a major component of the wealth of many countries that do not have much physical, technological and human capital. The result can be a development policy that causes long-term damage under the guise of short-term benefit. In addition, a focus on an absolute growth figure for GDP as a whole or average GDP per capita can encourage policies that worsen income distribution.

In short, when GDP becomes the main indicator of a development policy, it can carry an ideological bias, by identifying growth with the production of goods and services, regardless of the costs - material, psychological, social or spiritual - of this growth. A development policy cannot be based solely or principally on an increase in production but it must be sustainable, fair (avoiding problems of inequality and poverty) and efficient, and it must foster or at least not obstruct values such as social cohesion, participation of citizens, a broad concept of quality of life and the development of moral values. However, these arguments are a criticism not of the GDP figure but of the ideological view that the purpose of economic activity is continued, unlimited growth of the production of goods and services measured by the GDP.

In any case, it is important not to confuse GDP with human well-being or welfare. GDP refers only to the material component of well-being. Giving absolute priority to that component may lead to ethically questionable positions, such as the predominance of "having" over "being" or the subordination of other human values to the attainment of material well-being.

\section{The Alternatives}

Many alternatives have been proposed to overcome the limitations of GDP. The first relevant attempts focused on the concept of sustainability, in its several dimensions: economic, social, environmental and institutional. Attempts to carry out green accounting involved the handling of several interrelated dimensions, which made analysis and comparison very difficult, especially due to the lack of a commonly accepted framework.

In 1972 William Nordhaus and James Tobin proposed the "measure of economic welfare" (MEW): an adjusted measurement of the national product including only those items that contribute directly to economic well-being, with deductions for capital consumption, "disamenities" (pollution, for example), "regrettable" activities and intermediate activities whose contribution is already included in other items, and additions to account for the well-being derived from leisure and nonmarket activities and some capital services.

Another measure was the Index of Sustainable Economic Welfare (ISEW). It was calculated by Herman Daly and John B. Cobb in much the same way as the MEW, with additions such as unpaid household labor and the net formation of man-made capital, and deductions to reflect resource depletion, income inequality and environmental damage. It was reformulated by Clifford Cobb and his collaborators as the genuine progress indicator (GPI), to include factors such as voluntary work, the cost of crime and family breakdown, and the cost of underemployment. Generally speaking, these indicators have yielded a much lower rate of growth than GDP, particularly since the 1970s, and often a declining trend. 
There have been many other measures, such as green GDP, the Gender-Related Development Index, and the Better Life Index. With a different purpose in mind, each year the United Nations estimates the Human Development Index (HDI), which combines indicators of life expectancy, educational attainment and adjusted real income.

The calculation of those multidimensional indicators had as its aim the accurate formulation of development policies. At first it was thought that it would be necessary to aggregate multiple dimensions in a single unit with the help of common metrics, whether physical (space, energy) or economic (prices). However, the calculations were not robust, their interpretations were contentious and, above all, they could be subject to manipulation for ideological reasons. Today, developments in the use of composite indicators have facilitated the management of multidimensional concepts without reductionism, provided the temptation of a single metric is resisted.

In recent years, economists have used international surveys to compare "happiness indicators" with GDP. In 1974 Easterlin posed the paradox that rising levels of per capita GDP did not contribute to greater happiness. More recent studies have found a positive correlation between happiness and other variables such as personal income, the generosity of the welfare state and life expectancy, and a negative correlation with factors such as average hours worked, environmental degradation, crime, inflation and unemployment. The use of such indexes offers many possibilities for the measurement of well-being and for the promotion of a broad spectrum of development policies.

- Antonio Argandoña 
See also Economic growth; Economics of well-being (postwelfarist economics); Environmental ethics; Environmentalism; Developing world; International Monetary Fund (IMF); Natural resources; Organization for Economic Cooperation and Development (OECD); Sustainability; United Nations Environment Program (UNEP); U.S. Bureau of Economic Analysis.

\section{Further Reading and References}

Bloem, A.M., Dippelsman, R.J., \& Mæhle, N.Ø. (2001). Quarterly National Accounts Manual: Concepts, Data Sources, and Compilation. Washington, D.C.: International Monetary Fund.

Cobb, C., Halstead, T., \& Rowe, J. (1995). The Genuine Progress Indicator. San Francisco, CA: Redefining Progress.

Daly, H., \& Cobb, J. (1989). For the Common Good. Boston: Beacon Press.

Easterlin, R.A. (1974). "Does Economic Growth Improve the Human Lot? Some Empirical Evidence.” In P.A. David \& M.W. Reder (eds.). Nations and Households in Economic Growth: Essays in Honour of Moses Abramovitz. New York, NY: Academic Press, 89-125.

Eurostat (2013). Handbook on Quarterly National Accounts - 2013 Edition. Luxembourg: Eurostat.

Fioramonti, L. (2013). Gross Domestic Problem: The Politics Behind the World's Most Powerful Number. London: Zed Books.

Fleurbaey, M. (2009). “Beyond GDP. The Quest for a Measure of Social Welfare.” Journal of Economic Literature, 47(4), 1029-1075.

Lequiller, F., \& Blades, D. (2014). Understanding National Accounts (2nd ed.). Paris: OECD.

Munda, G. (2015). “Beyond GDP: An Overview of Measurement Issues in Redefining 'Wealth.” Journal of Economic Surveys, 29(3), 403-422.

Nordhaus, W.D., \& Tobin, J. (1972). “Is Growth Obsolete?” In Economic Growth. Fiftieth Anniversary Colloquium (vol. 5). New York, NY: Columbia University Press.

Pearce, D.W., Markandya, A. \& Barbier, E.B. (1989). Blueprint for a Green Economy. London: Earthscan Publications.

Stiglitz, J.E., Sen, A., \& Fitoussi, J.-P. (2009). Report by the Commission on the Measurement of Economic Performance and Social Progress. Available at http://www.insee.fr/fr/publications-etservices/dossiers_web/stiglitz/doc-commission/RAPPORT_anglais.pdf

United Nations (2014). Human Development Report 2014 - Sustaining Human Progress: Reducing Vulnerabilities and Building Resilience. New York, NY: UN Development Program.

Van den Bergh, J.C.J.M. (2009). “The GDP Paradox.” Journal of Economic Psychology, 30(2), 117-135. 